MARTINS, Rosemiro dos Reis. Direitos fundamentais: o princípio da vedação do retrocesso e a perda da soberania nacional. Revista Eletrônica Direito e Política, Programa de Pós-Graduação Stricto Sensu em Ciência Jurídica da UNIVALI, Itajaí, v.10, n.3, $2^{\circ}$ quadrimestre de 2015. Disponível em: www.univali.br/direitoepolitica - ISSN 1980-7791.

\title{
DIREITOS FUNDAMENTAIS: O PRINCÍPIO DA VEDAÇÃO DO RETROCESSO E A PERDA DA SOBERANIA NACIONAL
}

\author{
FUNDAMENTAL RIGHTS: THE PRINCIPLE OF PROHIBITED RETROCESSION AND
}

THE LOSS OF NATIONAL SOVEREIGNTY

Rosemiro dos Reis Martins ${ }^{1}$

SUMÁRIO: Introdução; 1. Os tradicionais elementos componentes do Estado Nacional e a soberania; 2. O Poder Constituinte: conceito e características; 3. Direitos Humanos e Direitos Fundamentais; 4. O princípio da vedação do retrocesso dos direitos fundamentais sociais; 5. Jus cogens, soft law e controle de convencionalidade; 6. A atual crise econômica europeia e a redução de direitos sociais; Considerações finais; Referências das fontes citadas.

\section{RESUMO}

Este artigo versa sobre o aparente conflito entre a soberania nacional e o princípio da vedação do retrocesso, principalmente em momentos de crise econômica e social. Tendo como referência a crise enfrentada recentemente pelos países europeus, principalmente Grécia e Espanha, é analisado se o princípio da vedação do retrocesso poderia impedir a adoção de medidas legais e constitucionais destinadas à redução de direitos fundamentais pelos países em crise, sobretudo os direitos sociais. Para tanto se estuda os elementos constitutivos do Estado, o conceito de soberania e o conceito e natureza do poder constituinte, principalmente o originário, afirmando-se sua relevância como instrumento de defesa da soberania frente aos tratados e convenções internacionais. Também se diferenciam os conceitos de direitos do homem, direitos humanos e direitos fundamentais, em relação a sua positividade, exigibilidade, origem e hierarquia, o que leva ao estudo do controle de convencionalidade e à discussão quanto à existência de hierarquia entre as normas elaboradas internamente e aquelas elaboradas em sede de tratados e convenções internacionais.

PALAVRAS-CHAVE: Soberania; Direitos Fundamentais; Poder Constituinte; Princípio da Vedação do Retrocesso.

\footnotetext{
1 Bacharel em Direito pela Universidade Estadual de Maringá (UEM). Especialista em Direito Constitucional pela Universidade Estadual de Maringá (UEM). Analista Judiciário (Especialidade Área Judiciária) do Tribunal de Justiça do Estado do Paraná (TJPR). E-mail: miromartins@hotmail.com
} 
MARTINS, Rosemiro dos Reis. Direitos fundamentais: o princípio da vedação do retrocesso e a perda da soberania nacional. Revista Eletrônica Direito e Política, Programa de Pós-Graduação Stricto Sensu em Ciência Jurídica da UNIVALI, Itajaí, v.10, n.3, 20 quadrimestre de 2015. Disponível em: www.univali.br/direitoepolitica - ISSN 1980-7791.

\section{ABSTRACT}

This paper discusses the apparent conflict between national sovereignty and the not-retrogression principle, especially in times of economic and social crisis. Referring to the recent crisis facing European countries, especially Greece and Spain, we analyze whether the principle of the prohibition of the setback could hinder the adoption of constitutional and legal measures aimed at reducing fundamental rights by countries crisis, especially social rights. Therefore, the study of the elements of the state, the concept of sovereignty and the concept and nature of constituent power, mainly from becoming its relevance as an instrument for the defense of sovereignty against treaties and conventions international. Also differentiate the concepts of human rights, human rights and fundamental rights, in connection with his positivity, enforceability, origin and hierarchy, which leads to the study of the control of compliance and the discussion about the existence of the hierarchy of internally developed standards and those preparing to host the international treaties and conventions.

KEYWORDS: Sovereignty. Fundamental Rights. Constituent Power. NotRetrogression Principle.

\section{INTRODUÇÃo}

São elementos do Estado o território, o povo e o poder soberano. Este último não encontra nenhum outro que se iguale a ele dentro de um respectivo território, porém é limitado pela soberania de outros Estados. Teoricamente a soberania equipararia os Estados, impedindo que interviessem uns nos outros.

Assim sendo, poder-se-ia crer que todo povo ao instituir uma nova ordem constitucional estaria livre para estabelecê-la conforme seu entendimento, paixões, convicções, interesses, cultura e momento político. Todavia, não é isso que geralmente ocorre, pois com o advento dos direitos humanos a área de liberdade na criação de uma Constituição tem sido reduzida consciente ou inconscientemente. Um desses limitadores é o princípio da vedação do retrocesso, o qual preceitua que as conquistas de direitos feitas por um povo não podem ser olvidadas em um novo texto constitucional.

Em princípio, uma nova ordem constitucional poderia, sim, revogar outra anterior a ela, porém, tendo em consideração esse princípio, apenas em certo ponto uma nova Constituição poderia sobrepor-se a sua antecessora, pois os direitos fundamentais adquiridos por uma nação jamais poderiam ser retirados dela. 
MARTINS, Rosemiro dos Reis. Direitos fundamentais: o princípio da vedação do retrocesso e a perda da soberania nacional. Revista Eletrônica Direito e Política, Programa de Pós-Graduação Stricto Sensu em Ciência Jurídica da UNIVALI, Itajaí, v.10, n.3, 20 quadrimestre de 2015. Disponível em: www.univali.br/direitoepolitica - ISSN 1980-7791.

Entendemos que neste ponto ocorre uma limitação da soberania dos Estados recém-constituídos, a qual atingiria inclusive os Estados Nacionais já constituídos, principalmente quando do exercício do poder constituinte reformador.

Assim, o poder constituinte originário estaria perdendo algumas de suas características, ou melhor, estas estariam sendo abrandadas devido a um direito supranacional a ser respeitado, o qual não pode ser ignorado, tampouco violado. Por exemplo, um país que tenha abolido a pena de morte não poderia adotá-la novamente, nem se o povo reunido em plebiscito, por imensa maioria, sustentasse que deseja que tal punição fosse aplicada em seu meio.

Logo, esses direitos humanos supranacionais, mutatis mutandis, equiparariam os Estados soberanos a pessoas jurídicas relativamente capazes, os quais somente teriam autonomia para elaborar normas constitucionais e infraconstitucionais nos moldes de um suposto direito humano natural, ou melhor, supranacional, já estabelecido por órgãos internacionais.

Há de se crer que esta rigidez na defesa da intangibilidade dos direitos fundamentais e dos direitos humanos limita a atuação dos Estados Nacionais em tempos de crise, tolhendo-Ihes a soberania (independência/liberdade).

Portanto, a importância do referido tema é patente, pois a intangibilidade de direitos fundamentais e humanos pode afetar a soberania dos Estados Nacionais, principalmente por dois aspectos, quais sejam: a) os direitos humanos são reconhecidos por organismos internacionais através de tratados e convenções internacionais, os quais são concebidos por forças políticas e ideológicas cujos interesses não se pode aquilatar; b) muitas vezes estes tratados e convenções internacionais "aconselham" que estes direitos sejam inseridos no ordenamento jurídico dos países por meio de emendas constitucionais.

Logo, é possível aventar, com base na lógica da vedação do retrocesso, que, em um momento futuro qualquer, quando um Estado Soberano enfrente uma rigorosa crise econômica e social, a exemplo da que ocorre na Espanha e Grécia, estariam os governantes limitados pelos direitos fundamentais sociais, pois não 
MARTINS, Rosemiro dos Reis. Direitos fundamentais: o princípio da vedação do retrocesso e a perda da soberania nacional. Revista Eletrônica Direito e Política, Programa de Pós-Graduação Stricto Sensu em Ciência Jurídica da UNIVALI, Itajaí, v.10, n.3, 20 quadrimestre de 2015. Disponível em: www.univali.br/direitoepolitica - ISSN 1980-7791.

estariam aptos a reduzir ou adequar direitos sociais atribuídos aos cidadãos, principalmente trabalhadores e funcionários públicos, os quais gozariam de uma absoluta intangibilidade.

Diante desse quadro, talvez o princípio da ponderação dos direitos fundamentais seja a solução adequada, a fim de conciliar a necessidade de sobrevivência do Estado-Nação com a realização de tais direitos.

\section{OS TRADICIONAIS ELEMENTOS COMPONENTES DO ESTADO NACIONAL E A SOBERANIA}

São elementos do Estado: o território, o povo e o poder soberano. O território é "a base geográfica do Estado. É dizer, aquela parcela do globo terrestre que se encontra sob sua jurisdição. É elemento material, sem dúvida, essencial ao Estado onde ele exerce a sua soberania"².

Povo, que não se confunde com população, é: "O conjunto de indivíduos que (...) se unem para constituir o Estado, estabelecendo com este um vínculo jurídico de caráter permanente, participando da formação da vontade do Estado e do exercício do poder soberano" ${ }^{3}$.

Note-se que o conceito de população é muito mais amplo do que o conceito de povo. Sendo população o conjunto de pessoas que residem no território do Estado, sem necessariamente ter qualquer vínculo político-jurídico com ele. Já os indivíduos componentes do elemento povo possuem um vínculo jurídico com o Estado denominado nacionalidade, podendo adquirir o status de cidadão, conforme as regras constitucionais, de dado país.

Por fim, tem-se o poder soberano, também denominado governo, o qual difere de soberania que nada mais é do que o efeito perceptível da atuação daquele. 0 governo é uma delegação de soberania. "É a própria soberania posta em ação.

\footnotetext{
2 BASTOS, Celso Ribeiro. Curso de Teoria do Estado e Ciência Política. 5. ed. São Paulo: Celso Bastos Editora, 2002, p. 69.

3 DALLARI, Dalmo de Abreu. Elementos de Teoria Geral do Estado. 12. ed. São Paulo: Saraiva, 1986 , p. 85.
} 
MARTINS, Rosemiro dos Reis. Direitos fundamentais: o princípio da vedação do retrocesso e a perda da soberania nacional. Revista Eletrônica Direito e Política, Programa de Pós-Graduação Stricto Sensu em Ciência Jurídica da UNIVALI, Itajaí, v.10, n.3, 20 quadrimestre de 2015. Disponível em: www.univali.br/direitoepolitica - ISSN 1980-7791.

[...] Positivamente, é o conjunto das funções necessárias à manutenção da ordem jurídica e da administração pública"4. "Governo é a atividade pela qual se exerce internamente a soberania. É dupla, portanto, a face interna da soberania: uma como poder constituinte e outra como poder constituído" ${ }^{5}$.

A soberania não é elemento constitutivo do Estado, mas, sim, é uma qualidade do poder exercido por ele dentro e fora de seu território. Embora seja uma expressão do poder, a soberania é poder jurídico utilizado para fins jurídicos. A supremacia na ordem interna é condição de igualdade na ordem internacional.

Neste diapasão afirma Dalmo de Abreu Dallari, ipsis litteris: "[...] tem-se como soberano o poder que decide qual regra jurídica aplicável em cada caso, podendo, inclusive, negar a juridicidade da norma" ${ }^{\prime 6}$.

Assim, a soberania tem duas facetas, uma no plano internacional, a qual impede a ingerência não consentida de outros Estados e organismos internacionais na ordem interna de um Estado, e outra nacional (ou interna) que atribui a ele o exercício exclusivo da força juridicamente regulada no seu âmbito interno. Portanto, "Soberania é uma autoridade superior que não pode ser limitada por nenhum outro poder" ${ }^{\prime \prime}$.

Segundo a Escola Clássica, a soberania é una, indivisível, inalienável e imprescritível. A soberania é una porque não pode haver mais de uma autoridade soberana em um mesmo território; desta afirmação decorre que o poder soberano é indivisível, em que pese possa haver delegação de atribuições para facilitar a administração do Estado.

Igualmente, é característica da soberania, segundo esta escola, a inalienabilidade, pois o poder soberano pertence ao corpo social. "Os delegados e representantes eleitos hão de exercer o poder de soberania segundo a vontade

\footnotetext{
${ }^{4}$ MALUF, Sahid. Teoria Geral do Estado. 23. ed. São Paulo: Saraiva, 1995, p. 27.

${ }^{5}$ CUNHA, Sérgio Sérvulo da. Fundamentos de Direito Constitucional: Constituição, Tipologia Constitucional, Fisiologia Constitucional. São Paulo: Saraiva, 2004, p. 27.

${ }^{6}$ DALLARI, Dalmo de Abreu. Elementos de Teoria Geral do Estado, p. 70.

7 MALUF, Sahid. Teoria Geral do Estado, p. 29.
} 
MARTINS, Rosemiro dos Reis. Direitos fundamentais: o princípio da vedação do retrocesso e a perda da soberania nacional. Revista Eletrônica Direito e Política, Programa de Pós-Graduação Stricto Sensu em Ciência Jurídica da UNIVALI, Itajaí, v.10, n.3, $2^{\circ}$ quadrimestre de 2015. Disponível em: www.univali.br/direitoepolitica - ISSN 1980-7791.

do corpo social consubstanciada na Constituição e nas Leis" ${ }^{8}$.

Assim, tal poder seria imprescritível, porque não poderia sofrer limitação no tempo. "Uma nação, ao se organizar em Estado soberano, o faz em caráter definitivo e eterno. Não se concebe soberania temporária, ou seja, por tempo delimitado" ${ }^{\prime 9}$. Embora a soberania seja dotada dessas quatro características, Sahid Maluf indica três elementos limitadores dela, quais sejam: os princípios de direito natural; o direito grupal (direito de grupos particulares que compõem o Estado); e os imperativos da coexistência pacífica dos povos na órbita internacional.

A nosso ver o direito grupal, decorrente de ordenamentos jurídicos internos, elaborados por grupos componentes do próprio Estado, tais como: a família, as associações, etc., não tem o condão de limitar a soberania nacional, pois é o próprio Estado que atribui validade aos ordenamentos jurídicos menores, os quais têm como base as diretrizes normativas postas por aquele.

Por sua vez, tem-se que os princípios de Direito Natural também limitariam a soberania "porque o Estado é apenas instrumento de coordenação do direito, e porque o direito positivo [...] só encontra legitimidade quando se conforma com as leis eternas e imutáveis da natureza"10. Embora se possa conceber que o direito positivado só é válido quando represente uma forma de positivação do direito natural, não se pode aceitar que o direito natural possa limitar a soberania do Estado, pelo menos sem ressalvas.

Primeiro, o conceito de direito natural é muito abstrato, ficando a interpretação dele condicionada às diversas correntes políticas e ideológicas, tanto que grupos contrários podem declarar dois direitos completamente antagônicos como um suposto direito natural, haja vista que os princípios são sujeitos à interpretação, enquanto que as regras seguem aos ditames do tudo ou nada. Com efeito,

\footnotetext{
${ }^{8}$ MALUF, Sahid. Teoria Geral do Estado, p. 33.

9 MALUF, Sahid. Teoria Geral do Estado, p. 33.

10 MALUF, Sahid. Teoria Geral do Estado, p. 37.
} 
MARTINS, Rosemiro dos Reis. Direitos fundamentais: o princípio da vedação do retrocesso e a perda da soberania nacional. Revista Eletrônica Direito e Política, Programa de Pós-Graduação Stricto Sensu em Ciência Jurídica da UNIVALI, Itajaí, v.10, n.3, 20 quadrimestre de 2015. Disponível em: www.univali.br/direitoepolitica - ISSN 1980-7791.

Ronald Dworkin ${ }^{11}$, in verbis:

As regras são aplicáveis à maneira do tudo-ou-nada. Dados os fatos que uma regra estipula, então ou a regra é válida, e neste caso a resposta que ela fornece deve ser aceita, ou não é válida, e neste caso em nada contribui para a decisão.

Segundo, não se sabe quais são os interesses por detrás das interpretações dominantes do que seja um direito natural válido. Neste ponto cabe anotar o posicionamento de Norberto Bobbio ${ }^{12}$, o qual afirma que o direito positivo atual assimilou a característica da universalidade, anteriormente exclusiva do direito natural, in verbis:

O universalismo jurídico ressurge hoje não mais como crença num direito natural eterno, já estabelecido em caráter definitivo, mas como vontade tendente a constituir um único direito positivo, que reúna numa unidade todos os direitos positivos existentes, e que seja produto não da natureza, mas da história, e esteja não no início do desenvolvimento social e histórico (como o direito natural e o estado de natureza), mas no fim. A ideia do Estado mundial único é a ideia-limite do universalismo jurídico contemporâneo; é uma unidade que se busca não contra o positivismo jurídico, com um retorno à ideia de um direito natural revelado à razão, mas através do desenvolvimento, até o limite extremo, do positivismo jurídico, ou seja, à constituição de um direito positivo universal.

Diante disso, não se poderia admitir que um Direito Natural amplamente abstrato estivesse apto a limitar a soberania nacional. O mesmo não se pode dizer a respeito dos direitos humanos e dos direitos fundamentais, os quais são normas, embora passíveis de interpretação, positivadas, quer seja na ordem internacional, quer seja na ordem interna.

Verifica-se, de acordo com o texto transcrito, que Norberto Bobbio, em meados do século passado, já vislumbrava o surgimento, mesmo que embrionário, de um

${ }^{11}$ DWORKIN, Ronald. Levando os Direitos a sério. São Paulo: Martins Fontes, 2011, p.39.

12 BOBBiO, Norberto. Teoria geral do direito. 3. ed. São Paulo: Martins Fontes, 2010, p. 316/317. 
MARTINS, Rosemiro dos Reis. Direitos fundamentais: o princípio da vedação do retrocesso e a perda da soberania nacional. Revista Eletrônica Direito e Política, Programa de Pós-Graduação Stricto Sensu em Ciência Jurídica da UNIVALI, Itajaí, v.10, n.3, 20 quadrimestre de 2015. Disponível em: www.univali.br/direitoepolitica - ISSN 1980-7791.

Estado mundial e de um ordenamento jurídico supranacional. Obviamente que esta tendência, até agora inevitável, em pouco tempo entrará em rota de colisão com o conceito de soberania.

Destarte, o princípio da coexistência pacífica das soberanias, o qual se coaduna com alguns dos princípios que regem as relações internacionais da República Federativa do Brasil na ordem internacional, previstos nos incisos do art. $4^{\circ} \mathrm{da}$ $\mathrm{CF} / 88$, seria o único dos limitadores da soberania aceitável, pois sabe-se que "as nações integram uma ordem continental, e, dentro dessa ordem superior, o poder de autodeterminação de cada uma limita-se pelos imperativos da preservação e da sobrevivência das demais soberanias"13.

Por derradeiro, a lição de Celso Ribeiro Bastos ${ }^{14}$, veja-se:

Um poder absolutamente infrene jamais existiu a começar pela óbvia razão de que todo poder está condicionado a circunstâncias de ordem econômica, social, demográfica, até mesmo tecnológica, que não podem ser alteradas por manifestações unilaterais do poder. [...] Contudo, é necessário salientar que a evolução da ordem jurídica estatal não tem feito senão restringir a margem de atuação livre e incondicionada do seu poder. [...] O Estado constitucional é aquele que só pode atuar nos limites das competências que Ihe são referidas pela Lei Maior.

Soberania hoje nada mais é do que um atributo da ordem jurídica estatal.

\section{O PODER CONSTITUINTE: CONCEITO E CARACTERÍSTICAS}

André Ramos Tavares ${ }^{15}$ conceitua o poder constituinte da seguinte forma, vejase:

\footnotetext{
13 MALUF, Sahid. Teoria Geral do Estado, p. 38.

${ }^{14}$ BASTOS, Celso Ribeiro. Curso de Teoria do Estado e Ciência Política, p. 98.

15 TAVARES, André Ramos. Curso de Direito Constitucional. 5. Ed. São Paulo: Saraiva, 2007, p. 29.
} 
MARTINS, Rosemiro dos Reis. Direitos fundamentais: o princípio da vedação do retrocesso e a perda da soberania nacional. Revista Eletrônica Direito e Política, Programa de Pós-Graduação Stricto Sensu em Ciência Jurídica da UNIVALI, Itajaí, v.10, n.3, 20 quadrimestre de 2015. Disponível em: www.univali.br/direitoepolitica - ISSN 1980-7791.

[...] "poder" constituinte originário corresponde à possibilidade (poder) de elaborar e colocar em vigência uma Constituição em sua globalidade. Esta, por sua vez, entendese como o documento básico e supremo de um povo que, dando-Ihe a necessária unidade, organiza o Estado, dividindo os poderes (constituídos) e atribuindo competências, que assegura a necessária proteção aos direitos e garantias fundamentais dos indivíduos e traça outras regras que terão caráter cogente para o legislador ordinário [...], para o governante $[\ldots]$ e para a maior parte das funções públicas da República.

Assim, o poder constituinte é aquele que inaugura uma nova ordem constitucional, rompe com o passado, desarticula as estruturas político-sociais até então reinantes, e estabelece o caminho para o futuro de um povo em dado momento histórico, político, econômico, social e territorial. Há neste momento uma redistribuição do poder, uma readequação de forças sociais.

Este poder surge em plena potência, e não tem outro fundamento que não ele mesmo. Manoel Gonçalves Ferreira Filho ${ }^{16}$ qualifica como lógica a exigência de um poder constituinte superior a quaisquer outros poderes existentes, os quais, por essa razão, seriam chamados de poderes constituídos.

Com efeito, o poder constituinte possui uma coloração para cada fase em que se encontra. Quando se está a estabelecer uma nova ordem constitucional ele é poder constituinte originário, inicial, incondicionado juridicamente, ilimitado, autônomo e permanente; porém quando já há uma ordem constitucional instituída ele passa a atuar como poder constituinte derivado.

Pode-se afirmar que o Poder Constituinte é permanente, pois não desaparece com a realização de sua obra, ou seja, com a elaboração de uma nova Constituição, "permanece latente, manifestando-se novamente mediante uma nova Assembleia Nacional Constituinte ou um ato revolucionário"17.

André Ramos Tavares ao definir a natureza jurídica do poder constituinte aceita

${ }^{16}$ FERREIRA FILHO, Manoel Gonçalves. Curso de Direito Constitucional. 36 ed. São Paulo: Editora Saraiva, 2010, p. 47.

17 MORAES, Alexandre de. Direito Constitucional. 14. ed. São Paulo: Atlas, 2004, p. 58. 
MARTINS, Rosemiro dos Reis. Direitos fundamentais: o princípio da vedação do retrocesso e a perda da soberania nacional. Revista Eletrônica Direito e Política, Programa de Pós-Graduação Stricto Sensu em Ciência Jurídica da UNIVALI, Itajaí, v.10, n.3, 20 quadrimestre de 2015. Disponível em: www.univali.br/direitoepolitica - ISSN 1980-7791.

"que evidentemente se trata de uma potência, mas que não pode ser levada às últimas consequências, quanto mais no atual nível de internacionalização dos Estados $^{\prime 18}$.

\section{DIREITOS HUMANOS E DIREITOS FUNDAMENTAIS}

Antes de se falar em direitos humanos e direitos fundamentais, primeiro é necessário se falar em direitos do homem. Os direitos do homem estão ligados à existência de um suposto Direito Natural preexistente, porém ainda não positivado, "não se está falando de direitos positivados, mas de valores ligados à dignidade da pessoa humana que existem pelo simples fato de o homem ser homem"19.

Logo, os direitos do homem carregam em si a ideia de justiça, de liberdade, de igualdade, de solidariedade, de dignidade da pessoa humana, valores pregados pela tradição judaico-cristã que influenciou o mundo ocidental.

Michel Villey ${ }^{20}$ se mostra cético em relação a tais direitos, afirmando que os direitos do homem são irreais, porque impotentes diante da realidade fática, além do que não são direitos positivados, mas apenas um ideal, veja-se:

Os "direitos do homem" são irreais. Sua impotência é manifesta. [...] Os direitos humanos não são "direitos" no sentido do positivismo jurídico, mais um ideal: modelos de realização da liberdade individual (para Kant, o valor jurídico supremo) e de igualdade.

A observância dos direitos do homem não é exigível de um Estado ou de um organismo internacional, porque destituídos de positividade, porém descortinam parâmetros a serem seguidos na elaboração de normas jurídicas. O fato de não

\footnotetext{
18 TAVARES, André Ramos. Curso de Direito Constitucional, p. 36.

19 MARMELSTEIN, George. Curso de Direitos Fundamentais. 3a ed. São Paulo: Atlas, 2011, p. 31.

${ }^{20}$ VILLEY, Michel. 0 direito e os direitos humanos. São Paulo: Martins Fontes, 2007, p. 5/6.
} 
MARTINS, Rosemiro dos Reis. Direitos fundamentais: o princípio da vedação do retrocesso e a perda da soberania nacional. Revista Eletrônica Direito e Política, Programa de Pós-Graduação Stricto Sensu em Ciência Jurídica da UNIVALI, Itajaí, v.10, n.3, 20 quadrimestre de 2015. Disponível em: www.univali.br/direitoepolitica - ISSN 1980-7791.

serem positivados retira muito da efetividade deles, dificuldade suplantada pelos direitos humanos e pelos direitos fundamentais.

Os Direitos Humanos "são aqueles direitos essenciais para que o ser humano seja tratado com a dignidade que lhe é inerente e aos quais fazem jus todos os membros da espécie humana, sem distinção de qualquer espécie"21.

Note-se que, os direitos fundamentais são inseridos no ordenamento jurídico nacional por intermédio de normas constitucionais, ao passo que os direitos humanos pertencem ao plano internacional. Neste sentido Rafael Barreto ${ }^{22}$, vejase:

A expressão 'direitos humanos' é utilizada para se referir a direitos universalmente aceitos, positivados na ordem internacional, enquanto a expressão 'direitos fundamentais' é utilizada para se referir a direitos positivados na ordem interna do Estado.

Ao analisar os direitos fundamentais, Karel Vasak idealizou a teoria das gerações de direitos. Ele se inspirou na bandeira francesa para desenvolver a sua teoria. A liberdade é representada pela cor azul; a igualdade, pela branca; e a fraternidade, pela vermelha.

Conforme esboçado por George Marmelstein ${ }^{23}$, as três gerações, também conhecidas como dimensões, seriam definidas da seguinte forma, in verbis:

a) a primeira geração dos direitos seria a dos direitos civis e políticos, fundamentados na liberdade (liberté), que tiveram origem com as revoluções burguesas; b) a segunda geração, por sua vez, seria a dos direitos econômicos, sociais e culturais, baseados na igualdade (égalité), impulsionada pela Revolução Industrial e pelos problemas sociais por ela causados; c) por fim, a última geração seria a dos direitos de solidariedade, em especial o direito ao desenvolvimento, à paz e ao meio ambiente, coroando a tríade com a

21 PORTELA, Paulo Henrique Gonçalves. Direito Internacional Público e Privado. $4^{a}$ ed. Salvador: Juspodivm. 2012, p. 769.

22 BARRETO, Rafael. Direitos Humanos. 2a ed. Salvador: Juspodivm, 2012, p. 24.

23 MARMELSTEIN, George. Curso de Direitos Fundamentais, p. 41. 
MARTINS, Rosemiro dos Reis. Direitos fundamentais: o princípio da vedação do retrocesso e a perda da soberania nacional. Revista Eletrônica Direito e Política, Programa de Pós-Graduação Stricto Sensu em Ciência Jurídica da UNIVALI, Itajaí, v.10, n.3, 20 quadrimestre de 2015. Disponível em: www.univali.br/direitoepolitica - ISSN 1980-7791.

fraternidade (fraternité), que ganhou força após a Segunda Guerra Mundial, especialmente após a Declaração Universal dos Direitos Humanos, de 1948.

Paulo Bonavides ${ }^{24}$ acresce a estas três dimensões de direitos fundamentais mais duas, a quarta e a quinta dimensões de direitos fundamentais. A quarta dimensão trata dos direitos à democracia, informação e pluralismo, veja-se:

São direitos da quarta geração o direito à democracia, o direito à informação e o direito ao pluralismo. Deles depende a concretização da sociedade aberta do futuro, em sua dimensão de máxima universalidade, para a qual o mundo parece inclinar-se no plano de todas as relações de convivência.

Por sua vez, a quinta dimensão trata do direito à paz, in verbis:

O direito à paz é concebido ao pé da letra qual direito imanente à vida, sendo condição indispensável ao progresso de todas as nações, grandes e pequenas, em todas as esferas. [...] Elevou-se, assim, a paz ao grau de direito fundamental da quinta geração ${ }^{25}$.

Logo, a paz é condição necessária e indispensável para a realização dos demais direitos fundamentais, embora não seja suficiente, carecendo da concorrência de uma série de outros fatores sociais e políticos.

Por fim, a sexta dimensão de direitos fundamentais, qual seja: o direito à agua potável, cuja existência é defendida por Zulmar Fachin ${ }^{26}$, veja-se:

Afirma-se, agora, a existência de uma sexta dimensão de direitos fundamentais. A água potável, componente do meio ambiente ecologicamente equilibrado, exemplo de direito fundamental de terceira dimensão, merece ser destacada e

24 BONAVIDES, Paulo. Curso de Direito Constitucional. 5. ed. São Paulo: Malheiros, 1994. p. 572.

25 BONAVIDES, Paulo. A quinta geração de direitos fundamentais. Direitos Fundamentais e Justiça. Porto Alegre, n. 3, abr./jun., 2008, p. 82/93.

${ }^{26}$ FACHIN, Zulmar. Curso de Direito Constitucional. 5a ed. Rio de Janeiro: Forense. 2012, p. 228. 
MARTINS, Rosemiro dos Reis. Direitos fundamentais: o princípio da vedação do retrocesso e a perda da soberania nacional. Revista Eletrônica Direito e Política, Programa de Pós-Graduação Stricto Sensu em Ciência Jurídica da UNIVALI, Itajaí, v.10, n.3, 20 quadrimestre de 2015. Disponível em: www.univali.br/direitoepolitica - ISSN 1980-7791.

alçada a um plano que justifique o nascimento de uma nova dimensão de direitos fundamentais. [...] A escassez de água potável no mundo, sua má distribuição, seu uso desregrado e a poluição em suas mais diversas formas geraram uma grave crise, a comprometer a subsistência da vida no Planeta.

A defesa desse direito fundamental de sexta dimensão é deveras perigosa, pois se o direito à água é um direito de todos, por que não dizer: universal, a soberania, supostamente, não deverá ser empecilho para que os Estados ricos exijam seu acesso forçado ao direito em questão, a despeito da soberania dos Estados mais fracos econômica e belicamente.

As características principais dos direitos fundamentais são:

a) fundamentalidade: os direitos fundamentais são uma base valorativa, localizada em um plano normativo superior às demais leis.

b) historicidade: esses direitos são produto da evolução histórica dos povos.

c) universalidade: valem em todo lugar, em todo tempo e em relação a todas as pessoas.

d) inalienabilidade e imprescritibilidade: "os direitos fundamentais não se perdem com o tempo, sendo imprescritíveis inclusive quanto ao seu exercício" ${ }^{27}$. Os direitos fundamentais não caducam, nem podem ser alienados, são indisponíveis.

e) indivisibilidade: "a indivisibilidade dos direitos fundamentais faz com que tenhamos que tratar os direitos fundamentais das várias gerações de forma igual, pois se cuida de um mesmo gênero de direitos" ${ }^{28}$.

f) inexauribilidade: por serem históricos não estão listados em um rol taxativo, não se esgotam, surgindo a cada avanço da humanidade.

g) positividade: retrata a necessidade de que os direitos fundamentais sejam

27 ROTHENBURG, Walter Claudius. Direitos Fundamentais e suas Características. Cadernos de Direito Constitucional e Ciência Política. São Paulo: RT, ano 7, 1999, n. 29, p. 57.

${ }^{28}$ BREGA FILHO, Vladimir. Direitos Fundamentais na Constituição de 1988: conceito jurídico das expressões. São Paulo: Juarez de Oliveira, 2002, p. 62. 
MARTINS, Rosemiro dos Reis. Direitos fundamentais: o princípio da vedação do retrocesso e a perda da soberania nacional. Revista Eletrônica Direito e Política, Programa de Pós-Graduação Stricto Sensu em Ciência Jurídica da UNIVALI, Itajaí, v.10, n.3, 20 quadrimestre de 2015. Disponível em: www.univali.br/direitoepolitica - ISSN 1980-7791.

incorporados aos ordenamentos jurídicos dos Estados, porém esta positivação não é uma pura e simples edição de leis. Os direitos fundamentais devem ser positivados no seio da Constituição, ocupando o ápice da hierarquia das normas, dada a sua importância.

h) complementariedade e vinculatividade: os direitos fundamentais se complementam e se amoldam uns aos outros, a fim de que nenhum suplante 0 outro. Todos são aplicáveis, desde que de forma proporcional e razoável, sendo que estes direitos vinculam a todos, inclusive os Poderes Públicos e os particulares; razão pela qual, ao invés dos direitos do homem, são exigíveis.

i) aplicação imediata, ou seja: "os direitos fundamentais, dotados de normatividade, têm aplicação imediata (art. 50, § $\left.1^{\circ}\right)^{\prime 29}$.

Por fim, cabe indicar as funções dos direitos fundamentais:

a) função de defesa ou de liberdade: "A função de defesa ou de liberdade impõe ao Estado um dever de abstenção [...], ou seja, dever de respeitar os atributos que compõem a dignidade da pessoa humana" ${ }^{30}$;

b) função de prestação social: esta função atribui à pessoa o direito social de obter um benefício do Estado, veja-se:

Nesse sentido, cabe ao Estado agir de três formas distintas: a) direta (quando ele mesmo presta o serviço); b) indireta (quando ele cria as condições e o particular presta os serviços); c) mista (o particular presta os serviços, porém o Estado remunera, como parece ser o caso de programas sociais de acesso à Universidade) ${ }^{31}$.

c) função de proteção perante terceiros: o Estado deve proteger a pessoa contra as agressões de terceiros. Neste ponto há a eficácia horizontal dos direitos fundamentais, quando tais direitos além de protegerem os indivíduos perante o Estado, passam a aplicar-se também na solução dos conflitos interindividuais, ou

\footnotetext{
${ }^{29}$ FACHIN, Zulmar. Curso de Direito Constitucional, p. 239.

${ }^{30}$ FACHIN, Zulmar. Curso de Direito Constitucional, p. 241.

${ }^{31}$ FACHIN, Zulmar. Curso de Direito Constitucional, p. 242.
} 
MARTINS, Rosemiro dos Reis. Direitos fundamentais: o princípio da vedação do retrocesso e a perda da soberania nacional. Revista Eletrônica Direito e Política, Programa de Pós-Graduação Stricto Sensu em Ciência Jurídica da UNIVALI, Itajaí, v.10, n.3, 20 quadrimestre de 2015. Disponível em: www.univali.br/direitoepolitica - ISSN 1980-7791.

seja, nas questões entre dois indivíduos no mesmo patamar de poder.

d) função de não discriminação: estes direitos não devem ser negados a ninguém, todos devem ter acesso a eles em respeito ao princípio da igualdade.

Portanto, os direitos fundamentais representam a atuação estatal limitada pelo direito (princípio da legalidade); o dever do Estado de prestar serviços aos seus cidadãos, ou pelo menos, permitir que terceiros os prestem com qualidade; a ponderação de direitos, a fim de assegurar o gozo de direitos mínimos a todos; e, o direito de não ser discriminado, o que garante que todos tenham direito de acesso e exercício de seus direitos fundamentais.

\section{O PRINCÍPIO DA VEDAÇÃo do RETROCESSO DOS DIREITOS FUNDAMENTAIS SOCIAIS}

Tendo em conta a relevância dos direitos fundamentais, além do árduo caminho trilhado para o estabelecimento deles, surge na doutrina o princípio da vedação do retrocesso, o qual preceitua que os direitos conquistados pelos cidadãos não podem ser deles retirados sem o oferecimento de alternativas ou compensações, ou seja, a conquista de direitos é gradual e contínua, sujeita a estagnações, porém, em caso de regressões, seu núcleo essencial deve ser preservado.

J. J. Gomes Canotilho ${ }^{32}$ conceitua o princípio da vedação do retrocesso:

O princípio da proibição do retrocesso social pode formularse assim: o núcleo essencial dos direitos sociais já realizado e efectivado através de medidas legislativas (...) deve considerar-se constitucionalmente garantido sendo inconstitucionais quaisquer medidas estaduais que, sem a criação de outros esquemas alternativos ou compensatórios, se traduzam na prática numa 'anulação' pura e simples desse núcleo essencial. A liberdade de conformação do legislador e inerente auto-reversibilidade têm como limite o núcleo essencial já realizado.

\footnotetext{
${ }^{32}$ CANOTILHO, José Joaquim Gomes. Direito Constitucional e Teoria da Constituição, p. 340.
} 
MARTINS, Rosemiro dos Reis. Direitos fundamentais: o princípio da vedação do retrocesso e a perda da soberania nacional. Revista Eletrônica Direito e Política, Programa de Pós-Graduação Stricto Sensu em Ciência Jurídica da UNIVALI, Itajaí, v.10, n.3, 20 quadrimestre de 2015. Disponível em: www.univali.br/direitoepolitica - ISSN 1980-7791.

O princípio da vedação do retrocesso, ou efeito cliquet, tem como pano de fundo a característica da historicidade dos direitos fundamentais, a qual retrata a progressividade da aquisição de direitos.

Nesta sistemática, em tese, a regressão na escalada de aquisição de direitos não é admitida, a não ser que haja uma justificativa relevante. A mera supressão de direitos fundamentais não é aceitável, porém sua mitigação torna-se uma alternativa, o que se dará de forma excepcional.

De acordo com Luís Roberto Barroso a vedação do retrocesso é uma ideia que começa a ganhar curso na doutrina constitucional brasileira, porque este princípio, que não é expresso, mas decorre do sistema jurídico-constitucional brasileiro, preceitua que se "uma lei, ao regulamentar um mandamento constitucional, instituir determinado direito, ele se incorpora ao patrimônio jurídico da cidadania e não pode ser arbitrariamente suprimido" ${ }^{33}$.

Logo, conclui-se que o princípio da vedação do retrocesso é um direito constitucional implícito que tem relação com a efetividade das normas constitucionais, sobretudo com aquelas que regulam direitos sociais, as quais não podem ser abolidas imotivadamente, sob pena de se incorrer em um retrocesso indevido.

Neste mesmo diapasão, ensina George Marmelstein 34: "somente seria possível cogitar na revogação de direitos sociais se fossem criados mecanismos jurídicos capazes de mitigar os prejuízos decorrentes de sua supressão".

Logo, um direito fundamental somente poderia ser suprimido ou flexibilizado caso fosse oferecida uma alternativa razoável em seu lugar. É inviável suprimir pura e simplesmente direitos fundamentais. Nesta esteira assevera Zulmar Fachin $^{35}$, ipsis litteris:

\footnotetext{
${ }^{33}$ BARROSO, Luís Roberto. O direito constitucional e a efetividade das normas. 9a ed. Rio de Janeiro: Renovar, 2009, p. 152.

${ }^{34}$ MARMELSTEIN, George. Curso de Direitos Fundamentais. 3a ed. São Paulo: Atlas, 2011, p. 303.

${ }^{35}$ FACHIN, Zulmar. Curso de Direito Constitucional, p. 249.
} 
MARTINS, Rosemiro dos Reis. Direitos fundamentais: o princípio da vedação do retrocesso e a perda da soberania nacional. Revista Eletrônica Direito e Política, Programa de Pós-Graduação Stricto Sensu em Ciência Jurídica da UNIVALI, Itajaí, v.10, n.3, 20 quadrimestre de 2015. Disponível em: www.univali.br/direitoepolitica - ISSN 1980-7791.

Registre-se [...] ser ponderável afirmar que um direito fundamental, considerado cláusula pétrea e pertencente ao bloco dos direitos comuns a todas as sociedades, não pode ser revogado nem mesmo por obra do poder constituinte originário.

Depreende-se desses ensinamentos que o princípio da vedação do retrocesso possui algumas características bastante claras, quais sejam: a) trata-se de princípio constitucional implícito; b) garantidor da efetividade das normas constitucionais; c) assegurador da segurança jurídica; e d) portador de certa relatividade, a qual fica condicionada pela manutenção de um núcleo mínimo de direitos ou do oferecimento de alternativas ou compensações legais.

Assim sendo, em tese, o poder constituinte originário seria passível de limitação, além do que a relativa irretroatividade dos direitos fundamentais permitiria que o Estado pudesse em tempos de crise mitigar direitos com o objetivo de garantir sua subsistência na ordem internacional.

A doutrina sustenta que o poder constituinte originário é dotado, em regra, de três características, quais sejam: inicialidade, incondicionamento jurídico e permanência. Sergio Roberto Leal dos Santos ${ }^{36}$ as caracteriza da seguinte forma:

\begin{abstract}
A inicialidade, que designa a qualidade de ser capaz de inaugurar uma nova ordem jurídica, é uma das características de maior relevância atribuídas ao poder constituinte, porquanto permite concluir que com o advento de uma nova Carta Constitucional ocorre uma verdadeira novação do direito [...]. Por materializar a própria vontade do titular da soberania, o poder constituinte não se prende às amarras do ordenamento jurídico anterior. Ao contrário, ele pode manifestar-se de modo livre e juridicamente incondicionado. [...] o poder constituinte permanece como uma força que não desaparece.
\end{abstract}

Destarte, a irretroatividade núcleo básico dos direitos fundamentais entra em conflito com o poder constituinte originário, isto tendo como parâmetro as características elencadas pela doutrina.

\footnotetext{
${ }^{36}$ SANTOS, Sergio Roberto Leal dos. Manual de Teoria da Constituição, p. 133.
} 
MARTINS, Rosemiro dos Reis. Direitos fundamentais: o princípio da vedação do retrocesso e a perda da soberania nacional. Revista Eletrônica Direito e Política, Programa de Pós-Graduação Stricto Sensu em Ciência Jurídica da UNIVALI, Itajaí, v.10, n.3, 20 quadrimestre de 2015. Disponível em: www.univali.br/direitoepolitica - ISSN 1980-7791.

Por conta disso, pode-se afirmar que o conceito de soberania está em crise, pois este atributo do Estado vem perdendo importância, sobretudo com o advento de órgãos internacionais, onde são elaboradas normas supranacionais através de tratados e convenções internacionais, e com o surgimento de uma sociedade globalizada.

Para Lenio Streck a questão da crise da soberania nacional ganha novos contornos diante do surgimento de poderes diversos no cenário jurídico (concorrentes), muitas vezes com capacidade decisória igual ou superior à dos Estados, como ocorre, e. g., com a construção das nominadas comunidades supranacionais ${ }^{37}$.

A despeito disso, cabe anotar que para a teoria da autolimitação a soberania nacional não está em crise, em verdade, "o Estado pode assumir, espontaneamente, limitações externas, a partir de compromissos assumidos perante outros poderes congêneres ${ }^{\prime 38}$, ou seja, para essa teoria a autolimitação também representaria o exercício da soberania.

Com efeito, as relações sociais e jurídicas se tornaram complexas, o mercado de consumo se globalizou, as relações sociais também, agora o ser humano é um cidadão local e mundial ao mesmo tempo, tal a velocidade da informação e da eficiência dos meios de comunicação.

Quanto à redução do protagonismo dos Estados nacionais, Octavio Ianni ${ }^{39}$ afirma que:

Parece reduzir-se o significado da soberania nacional, já que o estado-nação começa a ser obrigado a compartilhar ou aceitar decisões e diretrizes provenientes de centros de poder regionais e mundiais. Assim como a cidadania tem sido principalmente tutelada, regulada ou administrada, também a soberania nacional passa a ser crescentemente tutelada, regulada ou administrada. Se, por um lado, o

\footnotetext{
37 STRECK, Lenio Luiz; BOLZAN, José Luiz. Ciência Política e Teoria do Estado. 8. ed. Porto Alegre: Livraria do Advogado Editora, 2014, p.161.

${ }^{38}$ STRECK, Lenio Luiz; BOLZAN, José Luis. Ciência Política e Teoria do Estado, p.161.

39 IANNI, Octavio. A era do globalismo. 4a ed. Rio de Janeiro: Civilização Brasileira. 1999, p. $15 / 16$.
} 
MARTINS, Rosemiro dos Reis. Direitos fundamentais: o princípio da vedação do retrocesso e a perda da soberania nacional. Revista Eletrônica Direito e Política, Programa de Pós-Graduação Stricto Sensu em Ciência Jurídica da UNIVALI, Itajaí, v.10, n.3, 20 quadrimestre de 2015. Disponível em: www.univali.br/direitoepolitica - ISSN 1980-7791.

estado é levado a limitar e orientar os espaços da cidadania, por outro lado, as estruturas globais de poder são levadas a limitar e orientar os espaços da soberania nacional. [...] Acontece que a sociedade global já é uma realidade, ainda que em processo de formação e de institucionalização.

Logo, a soberania nacional estaria perdendo espaço, uma vez que as normas jurídicas, cada vez em maior número, advêm de um poder externo, reforçando a característica de universalidade dos direitos fundamentais.

\section{JUS COGENS, SOFT LAW E CONTROLE DE CONVENCIONALIDADE}

Há atualmente algumas fontes de direito internacional público que relativizam a soberania dos Estados, cabendo, por ora, fazer a diferenciação entre aquelas que se reputam as mais importantes: jus cogens e soft law.

As normas imperativas, ou seja, o jus cogens, são normas rígidas, limitadoras da soberania dos Estados na celebração de tratados internacionais; ao passo que o soft law se caracteriza por ser mais flexível, cujo caráter vinculante ainda é muito débil, porém cada uma, a sua maneira, vincula e obriga os Estados.

Em relação ao jus cogens, tem-se que:

A noção de jus cogens é definida pelo artigo 53 da Convenção de Viena sobre o Direito dos Tratados, que estabelece que "É nulo um tratado que, no momento de sua conclusão, conflite com uma norma imperativa de Direito Internacional geral. Para os fins da presente Convenção, uma norma imperativa de Direito Internacional geral é uma norma aceita e reconhecida pela comunidade internacional dos Estados como um todo como norma da qual nenhuma derrogação é permitida e que só pode ser modificada por norma ulterior de Direito Internacional geral da mesma natureza" [...]. A principal característica do jus cogens é a imperatividade de seus preceitos, ou seja, a impossibilidade de que suas normas sejam confrontadas ou derrogadas por qualquer outra norma internacional, inclusive aquelas que tenham emergido de acordos de vontades entre sujeitos de Direito das gentes. O jus cogens configura, portanto, restrição direta da soberania em nome da defesa de certos 
MARTINS, Rosemiro dos Reis. Direitos fundamentais: o princípio da vedação do retrocesso e a perda da soberania nacional. Revista Eletrônica Direito e Política, Programa de Pós-Graduação Stricto Sensu em Ciência Jurídica da UNIVALI, Itajaí, v.10, n.3, 20 quadrimestre de 2015. Disponível em: www.univali.br/direitoepolitica - ISSN 1980-7791.

valores vitais ${ }^{40}$

Destarte, o jus cogens prevalece sobre todas as outras fontes do Direito Internacional Público, em virtude de sua posição hierarquicamente superior às demais normas convencionais.

Em relação ao jus cogens, Valerio de Oliveira Mazzuoli ${ }^{41}$ assevera que:

Em suma, o procedimento normativo do jus cogens está a indicar a existência de uma nova e soberana fonte do Direito Internacional Público, formada por normas imperativas e reconhecidas pela sociedade internacional como um todo, e que não constam no rol das fontes clássicas do Direito Internacional estabelecido pelo art. 38 do Estatuto da Corte Internacional de Justiça. $O$ seu reconhecimento pela Convenção de Viena sobre o Direito dos Tratados de 1969 representou mais um fator de crise do voluntarismo, além de um fortalecimento da fundamentação do Direito Internacional Público.

Por seu lado, a soft law pode ser conceituada da seguinte maneira:

O soft law é uma das atuais modalidades de manifestação do fenômeno jurídico que não necessariamente incorporam as características clássicas do Direito. [...] O conceito foi desenvolvido pela doutrina norte-americana, em oposição à noção de hard law, que se refere ao Direito Internacional. [...] Em suma, o soft law inclui preceitos que ainda não se transformaram em normas jurídicas ou cujo caráter vinculante é muito débil [...] Com isso, é comum que as regras de soft law tenham caráter de meras recomendações ${ }^{42}$.

Ainda sobre soft law, conclui Valerio de Oliveira Mazzuoli ${ }^{43}$, veja-se:

\footnotetext{
40 PORTELA, Paulo Henrique Gonçalves. Direito Internacional Público e Privado, p. 87/88.

41 MAZZUOLI, Valerio de Oliveira. Curso de Direito Internacional Público. 5. Ed. São Paulo: RT, 2011, p. 156.

42 PORTELA, Paulo Henrique Gonçalves. Direito Internacional Público e Privado, p. 90/91.

43 MAZZUOLI, Valerio de Oliveira. Curso de Direito Internacional Público, p. 160.
} 
MARTINS, Rosemiro dos Reis. Direitos fundamentais: o princípio da vedação do retrocesso e a perda da soberania nacional. Revista Eletrônica Direito e Política, Programa de Pós-Graduação Stricto Sensu em Ciência Jurídica da UNIVALI, Itajaí, v.10, n.3, 20 quadrimestre de 2015. Disponível em: www.univali.br/direitoepolitica - ISSN 1980-7791.

[...] o seu conteúdo jurídico não se encontra ainda totalmente formalizado e sua natureza jurídica não está ainda perfeitamente delineada, o que retira boa parte da segurança científica necessária em se considerar o fenômeno como nova fonte do Direito Internacional Público.

O soft law tem grande influência na produção legislativa dos Estados soberanos, sua relevância é evidente.

Por sua vez, o controle de convencionalidade está relacionado ao conflito entre um tratado internacional de direitos humanos, integrado à Constituição Federal por intermédio do seu art. 50, $\S 3^{\circ}$, e uma norma de direito interno.

Existem, então, normas de nível constitucional, reconhecidas pelo art. $5^{\circ}, \S 2^{\circ}$, da $\mathrm{CF} / 88$, e normas equivalentes a emendas constitucionais, reconhecidas pelo art. 50, § $3^{\circ}$, da $\mathrm{CF} / 88$. As primeiras ensejariam o controle de convencionalidade das normas apenas por via de exceção, ao passo que as segundas dariam azo, tanto ao controle difuso, quanto ao controle concentrado de convencionalidade.

Valerio de Oliveira Mazzuoli ${ }^{44}$ conceitua o controle de convencionalidade:

O controle de convencionalidade das leis, que nada mais é que o processo de compatibilização vertical (sobretudo material) das normas de Direito interno com os comandos encontrados nas convenções internacionais de direitos humanos. À medida que os tratados de direitos humanos ou são materialmente constitucionais (art. $5^{\circ}, \S 2^{\circ}$ ), ou material e formalmente constitucionais (art. $50, \S 3^{\circ}$ ), é lícito entender que o clássico controle de constitucionalidade deve agora dividir espaço com esse novo tipo de controle ("de convencionalidade") da produção normativa doméstica.

Nesta esteira, o referido autor sustenta que as normas decorrentes de tratados internacionais são superiores hierarquicamente às normas de direito interno, possuindo aquelas uma espécie de supralegalidade, veja-se:

\footnotetext{
${ }^{44}$ MAZZUOLI, Valerio de Oliveira. Curso de Direito Internacional Público, p. 379/380.
} 
MARTINS, Rosemiro dos Reis. Direitos fundamentais: o princípio da vedação do retrocesso e a perda da soberania nacional. Revista Eletrônica Direito e Política, Programa de Pós-Graduação Stricto Sensu em Ciência Jurídica da UNIVALI, Itajaí, v.10, n.3, 20 quadrimestre de 2015. Disponível em: www.univali.br/direitoepolitica - ISSN 1980-7791.

Primeiramente, sabe-se (contrariamente ao que ainda pensa o STF) que os tratados internacionais comuns (aqueles que versam temas alheios aos direitos humanos) também têm status superior ao das leis internas. Se bem que não equiparados às normas constitucionais, os instrumentos convencionais comuns (como sempre defendemos, com base no art. 27 da Convenção de Viena sobre o Direito dos Tratados, de 1969, ratificada pelo Brasil em setembro de 2009) têm hierarquia supralegal em nosso país, posto não poderem ser revogados por lei interna posterior [...]. Nesse último caso, tais tratados (comuns) também servem de paradigma ao controle das normas infraconstitucionais, posto estarem situados acima delas, com a única diferença (em relação aos tratados de direitos humanos) que não servirão de paradigma do controle de convencionalidade (expressão reservada aos tratados com nível constitucional), mas do controle de supralegalidade das normas infraconstitucionais. Assim, as leis contrárias aos tratados comuns são inválidas por violação ao princípio da hierarquia, uma vez que tais tratados (sendo supralegais) acima deles se encontram ${ }^{45}$.

Data venia, entendemos que a posição do referido autor é inconstitucional por violar o princípio da soberania nacional, fundamento da República Federativa do Brasil (art. 10, I, da CF/88), pois tratados comuns celebrados no âmbito externo não podem prevalecer sobre novas decisões legais tomadas no âmbito interno.

Obviamente, a simples edição de uma norma contrária a um tratado internacional pode até ter efeitos internos, porém são necessários certos procedimentos para que tenham também efeitos externos, neste ponto entra a necessidade da denúncia do tratado, correndo-se o risco de que o Estado, com a reiteração desse tipo de procedimento, perca credibilidade no cenário internacional. O melhor é que o Estado não se comprometa com o que não irá cumprir.

Não obstante, verifica-se que a superioridade hierárquica dos tratados que versem sobre direitos humanos é inafastável, por expressa previsão constitucional (art. 5, §§ $2^{\circ}$ e $3^{\circ}$, da CF/88).

\footnotetext{
${ }^{45}$ MAZZUOLI, Valerio de Oliveira. Curso de Direito Internacional Público, p. 383.
} 
MARTINS, Rosemiro dos Reis. Direitos fundamentais: o princípio da vedação do retrocesso e a perda da soberania nacional. Revista Eletrônica Direito e Política, Programa de Pós-Graduação Stricto Sensu em Ciência Jurídica da UNIVALI, Itajaí, v.10, n.3, $2^{\circ}$ quadrimestre de 2015. Disponível em: www.univali.br/direitoepolitica - ISSN 1980-7791.

\section{A ATUAL CRISE ECONÔMICA EUROPEIA e A REDUÇÃo DE DiREITOS SOCIAIS}

O efeito cliquet, segundo Rafael de Oliveira $\operatorname{Costa}^{46}$, traz segurança jurídica às relações sociais, protegendo o cidadão das mudanças da sociedade, in verbis:

O princípio da vedação do retrocesso, também conhecido como efeito "cliquet" ou princípio da não-reversibilidade dos direitos fundamentais sociais [...] aparece, nesses casos, como garantia do indivíduo frente aos avanços e à necessidade de mudança, ou seja, atua como meio de garantir um mínimo de continuidade no ordenamento jurídico, indispensável para assegurar de segurança jurídica e previsibilidade a um ordenamento em constante mudança.

Ou seja, o princípio da vedação do retrocesso protege a sociedade de mudanças repentinas e desarrazoadas, garantindo a lógica e a continuidade do ordenamento jurídico.

A segurança jurídica e a manutenção da confiança da sociedade nas relações jurídicas com o Estado (princípio da confiança) são elementos indispensáveis em tempo de crise política, institucional, social e econômica.

Por conseguinte, não é segredo que os países europeus estão enfrentando uma grave crise econômica, havendo países, como a Grécia, que nem mesmo conseguem pagar suas dívidas. A maioria destes países sofre de uma crise de liquidez. Os índices de desemprego são crescentes e os protestos só aumentam, veja-se:

O desemprego na Grécia cresceu quase um ponto percentual em junho, chegando a $24,4 \%$ da população economicamente ativa, de acordo com estatísticas divulgadas pelo governo nesta quinta-feira. A taxa subiu devido à intensa crise financeira provocada pelo aumento do endividamento público $[\ldots]$. Os números são revelados em meio aos estudos do governo grego para a aplicação de medidas de

${ }^{46}$ COSTA, Rafael de Oliveira. Segurança jurídica e (im)previsibilidade do Direito. Nomos. v. 34, n. 1, $2014 . \quad$ Disponível em: http://www.periodicos.ufc.br/index.php/nomos/article/view/1193/1159>. Acesso em: 21/07/2015. 
MARTINS, Rosemiro dos Reis. Direitos fundamentais: o princípio da vedação do retrocesso e a perda da soberania nacional. Revista Eletrônica Direito e Política, Programa de Pós-Graduação Stricto Sensu em Ciência Jurídica da UNIVALI, Itajaí, v.10, n.3, 20 quadrimestre de 2015. Disponível em: www.univali.br/direitoepolitica - ISSN 1980-7791.

austeridade para conter a crise da dívida pública. Os cortes deverão chegar a $€ 11,5$ bilhões e afetarão áreas como a previdência e a geração de empregos. [...] As medidas de austeridade geram protestos da população ${ }^{47}$.

Estes países também passam por uma crise social, pois o Estado fundamentado na valorização dos direitos sociais cambaleia, sem forças para manter uma massa de servidores públicos, de desempregados ajudados por programas do governo e empresas públicas ineficientes. Note-se o caso da Itália:

O governo italiano aprovou nesta sexta-feira uma série de medidas para estimular o crescimento do país, que sofre os efeitos de uma grave crise econômica. As medidas incluem a venda de empresas e patrimônio estatais. [...] O governo anunciou também que vai reduzir o número de funcionários públicos por meio da fusão de departamentos, prevendo reduzir os funcionários do gabinete do primeiro-ministro e do ministro das Finanças em $10 \%{ }^{48}$.

Assim, acuados por órgãos internacionais, dentre eles o Fundo Monetário Internacional (FMI), estes países são forçados a cortar gastos, o que implica em demissão de funcionários públicos, privatizações e diminuição dos programas sociais do Estado.

Diante desse quadro, desempregados, muitos deles jovens mantidos pelos programas governamentais, saem às ruas para protestar, porque o Estado está deixando de assisti-los, o que influencia, inclusive, as eleições presidenciais nos países atingidos pela crise.

Obviamente são tempos de crise, não há emprego e o Estado não tem de onde retirar recursos para atender às necessidades de sua população. Com a falta de recursos, começa o corte de gastos menos essenciais.

47 DESEMPREGO cresce na Grécia e chega a 24,4\% em junho. Folha de São Paulo. Caderno Mundo. Disponível em: <http://www1.folha.uol.com.br/mundo/1149321-desemprego-cresce-na-greciae-chega-a-244-em-junho.shtml>. (MUNDO)

48 ITÁLIA anuncia pacote de privatizações para reduzir dívida pública. Zero Hora Economia. Disponível em: <http://zerohora.clicrbs.com.br/rs/economia/noticia/2012/06/italia-anunciapacote-de-privatizacoes-para-reduzir-divida-publica-3791761.html>. Acesso em: 20 out. 2012. 
MARTINS, Rosemiro dos Reis. Direitos fundamentais: o princípio da vedação do retrocesso e a perda da soberania nacional. Revista Eletrônica Direito e Política, Programa de Pós-Graduação Stricto Sensu em Ciência Jurídica da UNIVALI, Itajaí, v.10, n.3, 20 quadrimestre de 2015. Disponível em: www.univali.br/direitoepolitica - ISSN 1980-7791.

Contrariados com isso, os jovens sem perspectivas de futuro se insurgem contra o Estado e o FMI, elegendo-os como inimigos, não abrindo mão de seus benefícios, os quais classificam como direitos fundamentais. Tendo em conta estes fatos, pergunta-se: até que ponto estes direitos sociais, exigidos por estas pessoas de forma tão ferrenha, são fundamentais?

Será que o Estado deve manter privilégios até o seu inevitável fim? Ou será que nestes tempos difíceis, deve a população fazer sacrifícios para que o seu país não se extinga? Será que devido ao princípio da vedação do retrocesso, os Estados estão impedidos de fazer reformas constitucionais e legais que viabilizem o enfrentamento da crise?

Cabe afirmar que nenhum direito fundamental é absoluto, e que nenhum Estado estrangeiro ou organismo internacional deve impedir a alteração ou criação de uma constituição por determinado povo. Neste ponto, Norberto Bobbio ${ }^{49}$ :

O elenco dos direitos do homem se modificou, e continua a se modificar, com a mudança de condições históricas, ou seja, dos carecimentos e dos interesses, das classes no poder, dos meios disponíveis para a realização dos mesmos, das transformações técnicas, etc. Direitos que foram declarados absolutos no final do século XVIII, como a propriedade $[\ldots]$, foram submetidos a radicais limitações nas declarações contemporâneas; direitos que as declarações do século XVIII nem sequer mencionavam, como os direitos sociais, são agora proclamados com grande ostentação nas recentes declarações. Não é difícil prever que, no futuro, poderão emergir novas pretensões que no momento nem sequer podemos imaginar, como o direito a não portar armas contra a própria vontade, ou o direito de respeitar a vida também dos animais e não só dos homens. O que parece fundamental numa época histórica e numa determinada civilização não é fundamental em outras culturas. Não se concebe como seja possível atribuir um fundamento absoluto a direitos historicamente relativos. De resto, não há por que ter medo do relativismo.

Norberto Bobbio evidencia a historicidade dos direitos fundamentais. Eles se formam e consolidam conforme o decorrer da história, eles são voláteis, tanto

\footnotetext{
${ }^{49}$ BOBBIO, Norberto. A Era dos Direitos. Rio de Janeiro: Elsevier, 2004, p. 19.
} 
MARTINS, Rosemiro dos Reis. Direitos fundamentais: o princípio da vedação do retrocesso e a perda da soberania nacional. Revista Eletrônica Direito e Política, Programa de Pós-Graduação Stricto Sensu em Ciência Jurídica da UNIVALI, Itajaí, v.10, n.3, 20 quadrimestre de 2015. Disponível em: www.univali.br/direitoepolitica - ISSN 1980-7791.

que o direito fundamental reconhecido em um país rico não será necessariamente aquele reconhecido em um país pobre. Mesmo coexistindo em um mesmo plano temporal, dois países podem experimentar momentos distintos em termos de direitos fundamentais, pois eles são conquistados e dependem da maturidade de um povo.

Desta forma, é invasiva e contrária à soberania estatal a tendência de organismos internacionais e potências mundiais de impor direitos e comportamentos a países que se encontram em momento evolutivo diverso dos demais.

Se o Estado não consegue garantir os direitos mais básicos do cidadão por razões alheias a sua vontade, não há como seu povo exigir-lhe direitos fora desse mínimo, pelo menos temporariamente. Não é admissível que agentes externos the proíbam de procurar soluções para se reerguer, mesmo que isto implique na flexibilização de direitos trabalhistas, previdenciários e melhoria da máquina pública, por meio de demissões e racionalização do serviço.

Neste diapasão, Michel Villey ${ }^{50}$ ensina que a composição de direitos fundamentais e interesses é algo imensamente complicado, principalmente quando se está diante de direitos aparentemente antagônicos, veja-se:

Opte [...] pelo direito ao trabalho, à saúde, ao lazer e à cultura, eles parecerão difíceis de realizar sem cercear o direito de greve e as liberdades. [...] Certa literatura cristã progressista cultiva o sonho de reconciliar os direitos do homem de 1789 e os direitos "sociais e econômicos". Mas é a quadratura do círculo. [...] Cada um dos pretensos direitos humanos é a negação de outros direitos humanos, e praticado separadamente é gerador de injustiças.

De fato, nem sempre todos os direitos fundamentais serão realizados e contemplados ao mesmo tempo, principalmente em situações limite. E para os países europeus em crise apenas restam duas alternativas: pagar suas dívidas com sacrifício, ou dar o "calote" e quebrar, o que na prática significa o fim de

\footnotetext{
${ }^{50}$ VILLEY, Michel. 0 direito e os direitos humanos, p. 7/8.
} 
MARTINS, Rosemiro dos Reis. Direitos fundamentais: o princípio da vedação do retrocesso e a perda da soberania nacional. Revista Eletrônica Direito e Política, Programa de Pós-Graduação Stricto Sensu em Ciência Jurídica da UNIVALI, Itajaí, v.10, n.3, 20 quadrimestre de 2015. Disponível em: www.univali.br/direitoepolitica - ISSN 1980-7791.

uma nação.

Desta forma, descortina-se um novo direito fundamental, aquele a um Estado economicamente equilibrado e internacionalmente autônomo.

Não bastassem as incertezas econômicas, ainda há a questão da soberania, onde o Estado em crise se vê pressionado pela sua população e pelos organismos internacionais a não cercear sua população de direitos que, dada a situação fática, seriam considerados momentaneamente supérfluos.

Paulo Bonavides ${ }^{51}$ analisa este fenômeno do choque entre universalização de direitos fundamentais e soberania nacional no Brasil com clareza:

O Brasil está sendo impelido para a utopia deste fim de século: a globalização do neoliberalismo, extraída da globalização econômica. O neoliberalismo cria, porém, mais problemas do que os que intenta resolver. Sua filosofia do poder é negativa e se move, de certa maneira, rumo à dissolução do Estado nacional, afrouxando e debilitando os laços de soberania e, ao mesmo passo, doutrinando uma falsa despolitização da sociedade. A globalização política neoliberal caminha silenciosa, sem nenhuma referência de valores. Mas nem por isso deixa de fazer perceptível um desígnio de perpetuidade do statu quo de dominação. Faz parte da estratégia mesma de formulação do futuro em proveito das hegemonias supranacionais já esboçadas no presente.

Os poderes locais tendem a se enfraquecer devido à globalização econômica, política e social. As diferenças nacionais tendem a diminuir, haja vista a criação de uma cultura mundial, um novo estilo de vida apreciado e desejado pela maioria das pessoas do planeta. O sentimento nacional está em extinção, pois as pessoas se sentem cidadãs do mundo, participantes de uma ideologia única, porém velada, desejosas por diversos direitos, os quais são irrealizáveis na situação atual de seus países. O conflito é certo numa sociedade imediatista e sedenta de direitos.

\footnotetext{
${ }^{51}$ BONAVIDES, Paulo. Curso de Direito Constitucional, p. 570/571.
} 
MARTINS, Rosemiro dos Reis. Direitos fundamentais: o princípio da vedação do retrocesso e a perda da soberania nacional. Revista Eletrônica Direito e Política, Programa de Pós-Graduação Stricto Sensu em Ciência Jurídica da UNIVALI, Itajaí, v.10, n.3, $2^{\circ}$ quadrimestre de 2015. Disponível em: www.univali.br/direitoepolitica - ISSN 1980-7791.

\section{CONSIDERAÇÕES FINAIS}

Talvez a garantia do mínimo vital seja a resposta, proporcionando à população um conjunto mínimo de direitos que lhes garanta a manutenção da humanidade. A situação econômica, política e social pode ser complexa e desafiadora, porém um mínimo de dignidade deve ser assegurado às pessoas. Em tempos de crise, mordomias e benefícios dispensáveis devem ser suprimidos, mas aqueles inerentes à manutenção da vida digna devem ser mantidos.

Em que pesem as dificuldades enfrentadas por um Estado, é aconselhável que o próprio povo descubra a melhor forma de se reerguer, isto em prestígio ao princípio da autodeterminação dos povos e para o auxílio à maturidade constitucional deles. Decisões unilaterais, impostas por agentes externos, devem ser evitadas.

Destarte, por enquanto, a soberania há de prevalecer em relação à universalização dos direitos fundamentais, fruto da globalização política, econômica e social, sob o risco de se aplicar normas fora de contexto.

De outro giro, para a manutenção dos Estados, evitando colapsos, melhor ceder um pouco hoje para voltar a evoluir amanhã, com isso prestigia-se os princípios da proporcionalidade e da razoabilidade, valoriza-se o bom senso.

Por fim, deve-se estar alerta para evitar que o discurso de efetivação de direitos fundamentais universais, pregado principalmente por potências mundiais, por exemplo, os Estados Unidos da América, seja mero pretexto, instrumento eficaz e politicamente correto de dominação de outros povos.

Vivemos o tempo do politicamente correto, temos medo de defender uma posição que choque os demais, embora ela seja a mais correta para o momento histórico, o que muitas vezes nos põem em uma "camisa de força", a qual nos impede de apontar os desmandos e o conteúdo subversivo de alguns discursos humanitários.

Os direitos fundamentais, sobretudo os sociais, advém do princípio da dignidade da pessoa humana. O princípio da vedação do retrocesso é uma garantia de 
MARTINS, Rosemiro dos Reis. Direitos fundamentais: o princípio da vedação do retrocesso e a perda da soberania nacional. Revista Eletrônica Direito e Política, Programa de Pós-Graduação Stricto Sensu em Ciência Jurídica da UNIVALI, Itajaí, v.10, n.3, 20 quadrimestre de 2015. Disponível em: www.univali.br/direitoepolitica - ISSN 1980-7791.

efetivação desses direitos, garantido a proteção dos cidadãos em face do Estado e suas arbitrariedades.

Uma sociedade para progredir deve buscar a estabilidade econômica, institucional, mas sobretudo a jurídica, a qual é capaz de tornar claro às pessoas as "regras do jogo", evitando-se com isso surpresas.

Neste ponto entra o princípio da confiança e da segurança jurídica, pois os direitos poderão ser mitigados, reduzidos, porém o povo deverá ter a certeza de que uma mínima parcela das conquistas sociais será mantida.

Portanto, um Estado só cumpre o seu papel quando garante direitos fundamentais a todos sem distinções; benefícios desproporcionais e fora de contexto não podem mais ser admitidos.

\section{REFERÊNCIAS DAS FONTES CITADAS}

BARRETO, Rafael. Direitos Humanos. 2a ed. Salvador: Juspodium, 2012.

BASTOS, Celso Ribeiro. Curso de Teoria do Estado e Ciência Política. 5. ed. São Paulo: Celso Bastos Editora, 2002.

BOBBIO, Norberto. A Era dos Direitos. Rio de Janeiro: Elsevier, 2004.

BOBBIO, Norberto. Teoria geral do direito. 3. ed. São Paulo: Martins Fontes, 2010.

BONAVIDES, Paulo. A quinta geração de direitos fundamentais. Direitos Fundamentais e Justiça. Porto Alegre, n. 3, abr./jun., 2008, p. 82/93.

BONAVIDES, Paulo. Curso de Direito Constitucional. 5. ed. São Paulo: Malheiros, 1994.

BREGA FILHO, Vladimir. Direitos Fundamentais na Constituição de 1988: conceito jurídico das expressões. São Paulo: Juarez de Oliveira, 2002.

CANOTILHO, José Joaquim Gomes. Direito Constitucional e Teoria da Constituição. 7a ed. Coimbra: Almedina, 2003.

COSTA, Rafael de Oliveira. Segurança jurídica e (im)previsibilidade do Direito. Nomos. v. 34, n. 1, 2014. Disponível em: http: //www.periodicos.ufc.br/index.php/nomos/article/view/1193/1159>. 
MARTINS, Rosemiro dos Reis. Direitos fundamentais: o princípio da vedação do retrocesso e a perda da soberania nacional. Revista Eletrônica Direito e Política, Programa de Pós-Graduação Stricto Sensu em Ciência Jurídica da UNIVALI, Itajaí, v.10, n.3, 20 quadrimestre de 2015. Disponível em: www.univali.br/direitoepolitica - ISSN 1980-7791.

CUNHA, Sérgio Sérvulo da. Fundamentos de Direito Constitucional: Constituição, Tipologia Constitucional, Fisiologia Constitucional. São Paulo: Saraiva, 2004.

DALLARI, Dalmo de Abreu. Elementos de Teoria Geral do Estado. 12. ed. São Paulo: Saraiva, 1986.

DESEMPREGO cresce na Grécia e chega a 24,4\% em junho. Folha de São Paulo. Caderno Mundo. Disponível em: <http://www1.folha.uol.com.br/mundo/1149321-desempregocresce-na-grecia-e-chega-a-244-em-junho.shtml>.

DWORKIN, Ronald. Levando os Direitos a sério. São Paulo: Martins Fontes, 2011.

FACHIN, Zulmar. Curso de Direito Constitucional. $5^{a}$ ed. Rio de Janeiro: Forense. 2012.

FERREIRA FILHO, Manoel Gonçalves. Curso de Direito Constitucional. 36 ed. São Paulo: Editora Saraiva, 2010.

IANNI, Octavio. A era do globalismo. $4^{a}$ ed. Rio de Janeiro: Civilização Brasileira. 1999.

ITÁLIA anuncia pacote de privatizações para reduzir dívida pública. Zero Hora Economia. Disponível em: <http://zerohora.clicrbs.com.br/rs/economia/noticia/2012/06/italiaanuncia-pacote-de-privatizacoes-para-reduzir-divida-publica-3791761.html> .

MALUF, Sahid. Teoria Geral do Estado. 23. ed. São Paulo: Saraiva, 1995.

MARMELSTEIN, George. Curso de Direitos Fundamentais. $3^{a}$ ed. São Paulo: Atlas, 2011.

MAZZUOLI, Valerio de Oliveira. Curso de Direito Internacional Público. 5. Ed. São Paulo: RT, 2011.

MORAES, Alexandre de. Direito Constitucional. 14. ed. São Paulo: Atlas, 2004.

PORTELA, Paulo Henrique Gonçalves. Direito Internacional Público e Privado: incluindo noções de direitos humanos e de direito comunitário. $4^{a}$ ed. Salvador: Juspodium. 2012.

ROTHENBURG, Walter Claudius. Direitos Fundamentais e suas Características. Cadernos de Direito Constitucional e Ciência Política. São Paulo: RT, ano 7, 1999 , n. 29.

SANTOS, Sergio Roberto Leal dos. Manual de Teoria da Constituição. São Paulo: Revista dos Tribunais. 2008. 
MARTINS, Rosemiro dos Reis. Direitos fundamentais: o princípio da vedação do retrocesso e a perda da soberania nacional. Revista Eletrônica Direito e Política, Programa de Pós-Graduação Stricto Sensu em Ciência Jurídica da UNIVALI, Itajaí, v.10, n.3, 20 quadrimestre de 2015. Disponível em: www.univali.br/direitoepolitica - ISSN 1980-7791.

TAVAReS, André Ramos. Curso de Direito Constitucional. 5. Ed. São Paulo: Saraiva, 2007.

VILLEY, Michel. 0 direito e os direitos humanos. São Paulo: Martins Fontes, 2007.

Submetido em: Junho/2015

Aprovado em: Julho/2015 